\title{
PENGARUH DESENTRALISASI FISKAL TERHADAP INFLASI DI PROPINSI NUSA TENGGARA BARAT
}

\section{The Impact of Fiscal Decentralization on Inflation in West Nusa Tenggara Province}

\author{
Rozzy Aprirachman ${ }^{1}$; Didi Suwardi ${ }^{1}$; Abdul Hadi Ilman ${ }^{1}$ \\ ${ }^{1}$ Program Studi Ekonomi Pembangunan, Fakultas Ekonomi dan Bisnis Universitas Teknologi Sumbawa \\ e-mail : rozzyrachman90@gmail.com
}

\begin{abstract}
This research is designed to find the effect of fiscal decentralization on inflation in West Nusa Tenggara (NTB) province during the period of 2010-2014 for ten districts in NTB in forms of panel data.. Fiscal Decentralization is proxied from the ratio of specific allocation fund (DAK) to the regional expenditure budget (APBD), ratio of general allocation fund (DAU) to APBD, ratio of revenue sharing fund (DBH) to APBD, and regional retribution. Meanwhile, inflation is proxied by the Gross Domestic Regional Product. Tool's analysis used in this research is multivariable linear regression by applying Fixed Effect Model (FEM) method. The results show that the ratio of DAK to APBD has a significant negative effect on inflation in the region with 95 percent significance level. If the DAK increased one unit then the inflation will be reduced by 0.1290144 unit. Meanwhile, the ratio of DAU to $A P B D$ has positive influence on inflation with coefficient value of 0.5825204. moreover, the ratio of DBH to APBD has positive effect on inflation with the value of the coefficient is 0,4592334. On the other hand, the regional retribution has negative and significant influence on inflation with coefficient 0.0003764 .
\end{abstract}

Keyword: Fiscal decentralization, Inflasi, Fixed Effect Model

\section{ABSTRAK}

Penelitian ini di desain untuk mencari pengaruh dari desentalisasi fiskal terhadap inflasi di Provinsi Nusa Tenggara Barat dari tahun 2010 -2014 dengan melihat data dari sepuluh kabupaten kota di NTB dalam bentuk data panel. Desentralisasi fiskal di proksi dari rasio DAK terhadap APBD, rasio DAU terhadap APBD, rasio DBH terhadap APBD, dan retri busi. Sedangkan inflasi diproksi dari PDRB Provinsi NTB. Alat analisis yang digunakan dalam penelitian ini adalah Regresi linear berganda dengan menggunakan metode Fixed Effect Model (FEM). Dari hasil penelitian dengan signifikansi 95 persen didapat bahwa Rasio DAK terhadap APBD berpengaruh negatif terhadap inflasi di NTB yaitu ketika DAK naik satu satuan maka inflasi di NTB akan berkurang sebesar 0,1290144 satuan . Rasio DAU Terhadap APBD berpengaruh positif terhdap inflas di NTB dengan koefisien sebesar 0.5825204, rasio DBH terhadap APBD berpengaruh positif terhadap inflsi sebesar 0,4592334 dan retribusi berpengaruh negatif dan signifikan terhadap inflasi di NTB dengan koefisien 0,0003764 .

Kata Kunci : Desentalisasi Fiskal, Inflasi, Model Fixed Effect

\section{Pendahuluan}

Bank Dunia (1997) menyebutkan bahwa antara desentralisasi fiskal dan pertumbuhan ekonomi mempunyai kemungkinan kondisi sebagai berikut: pertama, desentralisasi fiskal akan meningkatkan efisiensi pengeluaran pemerintah sehingga berdampak positif terhadap pertumbuhan; kedua, desentralisasi fiskal mempunyai dampak meningkatkan instabilitas makro ekonomi sehingga berdampak negatif terhadap pertumbuhan ekonomi; ketiga, desentralisasi fiskal untuk suatu daerah bisa berdampak positif ataupun negatif terhadap pertumbuhan ekonomi, hal tersebut tergantung kesiapan kelembagaan daerah tersebut dalam menjalankan kebijakan desentralisasi fiskal.

Berdasarkan temuan dari bank dunia tersebut, kajian ini akan fokus menganalisa kondisi kedua yaitu desentralisasi fiskal selain dapat berdampak pada pertumbuhan ekonomi, disisi lain juga bisa 
meningkatkan instabilitas makro ekonomi. Indikator dari instabilitas makro yang dimaksud adalah inflasi.

Dalam kaitannya dengan desentralisasi fiskal, para investor ekonomi berpendapat bahwa pajak/retribusi baru daerah merupakan hambatan sangat besar bagi pengembangan usaha dan investasi karena cenderung meningkatkan biaya produksi sehingga bersifat meningkatkan cost push inflation. Selanjutnya transfer dana dari pemerintah pusat ke pemerintah daerah dalam bentuk Dana Alokasi Umum, dana Alokasi Khusus, dan Dana Bagi Hasil, merupakan sumber utama penerimaan daerah yang berfungsi untuk menjamin dan menjaga tercapainya standar pelayanan minimum di suatu daerah, namun bisa juga berdampak sebaliknya karena kondisi keuangan masing-masing daerah yang tidak merata (Simanjuntak, 2002). Transfer dari pemerintah dalam bentuk Dana Alokasi Umum dan Dana Bagi Hasil diarahkan untuk menciptakan keseimbangan fiskal untuk mendorong pertumbuhan ekonomi untuk menyukseskan program-program nasional yang bersifat prioritas (Sidik 2002)

Pemilihan kabupaten dan kota di propinsi NTB dikarenakan kabupaten dan kota di propinsi NTB memperoleh dana perimbangn yang cukup besar dari pemerintah pusat dimana dana perimbangan seperti DAK, DAU, DBH dari pemerintah pusat lebih besar dari Pendapatan asli daerah masing- masing Kabupaten, bahkan dana perimbangn lebih besar $300 \%$ dari PAD kabupaten di NTB sehingga menjadi menarik untuk diteliti dana yang begitu besar dari pusat apakah berpengaruh pada tingkat inflasi di NTB. Berikut proporsi dana perimbangan di kabupaten NTB 2014 yang merupakan indikator utama desentraliasasi fiskal selaian retribusi..

Dana perimbangan sebagai salah satu indikator utama desentalisasi fiskal ternyata justru menyumbang dana cukup besar untuk APBD dan disamping dana perimbangan ada juga variabel desentraliasi fiskal yang lain seperti UMR dan total pajak yang akan dibahas dalam penelitian ini. Berikut bukti perbandingan antara pendapatan asli daerah dengan dana perimbangan dari pemerintah pusat yaitu $92 \%$ untuk dana perimbangan dan $8 \%$ untuk PAD sehingga dalam mengontrol penggunaan dana tersebut cukup sulit dan sesuai dengan teori yang dijabarkan oleh bank dunia bahwa ketidaksiapan birokrasi di pemerintah daerah justru menimbulkan instabilitas ekonomi makro dan berpengaruh signifikan terhadap pertumbuhan ekonomi, yang berarti inflasi terjadi di daerah tersebut

Bedasarkan rumusan uraian diatas maka tujuan penelitian ini adalah sebagai berikut:

1. Mendapatkan bukti empiris mengenai pengaruh rasio Dana Alokasi Khusus (DAK) terhadap Anggaran pendapatan Belanja Daerah (APBD ) dan pengaruhnya terhadap inflasi di kabupaten dan kota di NTB

2. Mendapatkan bukti empiris mengenai pengaruh rasio Dana Alokasi Umum (DAU) terhadap Anggaran pendapatan Belanja Daerah (APBD) dan pengaruhnya terhadap inflasi di kabupaten dan kota di NTB

3. Mendapatkan bukti empiris mengenai pengaruh Dana Bagi Hasil (DBH) terhadap Anggaran pendapatan Belanja Daerah (APBD) dan pengaruhnya terhadap inflasi di kabupaten dan kota di NTB

4. Mendapatkan bukti empiris mengenai pengaruh Retribusi daerah terhadap inflasi di kabupaten dan kota di NTB

5. Mendapatkan bukti empiris mengenai pengaruh rasio DAK terhadap PAD, rasio DAU terhadap PAD, rasio DBH terhadap Anggaran pendapatan Belanja Daerah (APBD), dan Retribusi daerah secara bersama- sama terhadap inflasi di kabupaten dan kota di NTB

\section{Metodologi Penelitian}

Penelitian ini menggunakan analisis kualitatif dan analisis kuantitatif untuk menjawab permasalahan penelitian. Analisis kualitatif digunakan untuk menginterpretasikan hasil estimasi dalam model penelitian dengan menyesuaikannya pada studi empiris sebelumnya dan teori yang mendukung, sementara analisis kuantitatif digunakan untuk mengestimasi model ekonometrika.

Dalam penelitian ini penulis menggunakan model regresi linear berganda untuk mengestimasi inflasi yang diproksi dengan PDRB deflator. Penulis menggunakan inflasi yang diprosi dengan PDRB deflator sebagai variabel dependen, sementara variabel independennya yaitu rasio dana alokasi umum (DAU) terhadap Anggaran Pendapatan Belanja Daerah (APBD) dana rasio alokasi khusus (DAK) terhadap Anggaran Pendapatan Belanja Daerah (APBD), rasio dana bagi hasil (DBH) terhadap Anggaran Pendapatan Belanja Daerah (APBD), dan retribusi

Dalam penelitian ini, Penulis menggunakan model data panel untuk mengestimasi pengaruh desentralisasi fiskal terhadap inflasi di kabupaten kota di NTB yang diproksi dengan PDRB Deflator dan menggunakan analisis regresi linear berganda.

Inflasi $=\beta 1+\beta 2$.Rasio $D B H+\beta 3$.Rasio $D A U+\beta 4$.Rasio $D A K+\beta 4 . R e t+U i$ 
Keterangan:

Rasio DBH : Rasio Dana Bagi Hasil Terhadap APBD

Rasio DAU: Rasio Dana Alokasi Umum Terhadap APBD

Rasio DAK : Rasio Dana Alokasi Khusus Terhadap APBD

RET : Retribusi

Ada 3 macam pendekatan yang digunakan dalam menguji regresi data panel, yaitu:

\section{Pooled least square}

Pendekatan pooled least square juga sering disebut dengan common effect, merupakan pendekatan yang tidak memperhatikan dimensi atau runtut waktu meskipun data cross section digabung dengan data time series. Pendekatan ini merupakan pendekatan yang paling sederhana sehingga estimasi nilai $\alpha$ konstan dan sama untuk setiap perusahaan yang menjadi objek penelitian tanpa memperhatikan dimensi waktunya (Saleh, 2012:38).

\section{Pendekatan efek tetap (Fixed-effect)}

Metode yang mengindiksikan bahwa individu ataupun perusahaan memiliki intersep yang berbeda akan tetapi memiliki slope regresi yang sama dari waktu ke waktu. Teknik ini mengestimasikan data panel menggunakan variabel dummy untuk membedakan intersepnya. Model ini juga disebut dengan Least Square Dummy Variabel (LSDV).Akan tetapi dengan dimasukkannya variabel dummy maka akan membawa konsekuensi yaitu berkurangnya derajat kebebasan sehingga efisiensi parameter menjadi berkurang.

3. Pendakatan acak (Random Effect)

Random Effect Model adalah model etimasi regresi panel dengan asumsi koefisien slope kontan dan intersep berbeda antara individu dan antar waktu (Random Effect). Model ini mengasumsikan bahwa setiap individu atau perusahaan memiliki intersep yang berbeda yang merupakan variabel random atau stokastik (Setiawan, 2013:62).

Untuk memilih metode estimasi yang tepat diantara ketiga jenis metode yang tepat, diperlukan beberapa tahapan pengujian, yaitu:

\section{Uji Chow (F Restricted)}

Uji chow adalah pengujian untuk menentukan model Fixed Effect atau Common Effect yang lebih tepat digunakan dalam mengestimasi data panel.Hipotesis Uji Chow adalah:

\section{Ho : Common Effect Model atau Pooled OLS}

\section{Ha : Fixed Effect Model}

Tolak ukur penolakan hipotesis diatas adalah dengan melihat nila $\mathrm{F}$ yang dihasilkan. Jika nilai $\mathrm{F}<\alpha(\mathrm{F}<$
0.05) maka tolak Ho, artinya model yang tepat untuk digunakan adalah fixed effect model.

2. Breusch Pagan Lagrange Multiplier (LM) Test Pengujian yang dikenal dengan LM test ini merupakan pengujian statistik (formal) untuk menentukan pendekatan yang tepat antara PLS dengan random effect yang akan diterapkan dalam penelitian. Hipotesis pengujian LM test ini adalah sebagai berikut:

$$
\begin{aligned}
& \mathrm{Ho}=\mathrm{PLS} \\
& \mathrm{Ha}=\text { Random effect }
\end{aligned}
$$

Dasar penolakan adalah dengan melihat nilai probabilitas $F$, jika nilai probabilitas $F<\alpha$, maka tolak Ho.

\section{Hausman test}

Housman test adalah pengujian statistik untuk memilih pendekatan yang tepat untuk digunakan antara fixed effect atau random effect.

Hipotesis dari pengujian ini adalah:

$$
\begin{aligned}
& \mathrm{Ho}=\text { memakai random effect } \\
& \mathrm{Ha}=\text { memakai fixed effect }
\end{aligned}
$$

Suwardi (2011) menyebutkan bahwa dasar penolakan atas hipotesis diatas adalah:

Jika nilai Prob F < alfa, tolak Ho

Jika nilai Prob $\mathrm{F}>\alpha$, terima Ho

\section{Hasil dan Analisis}

Sebelum melakukan pengolahan data, penulis sudah terlebih dahulu melakukan cek deskriptif dan seting data panel yang digunakan dalam penelitian ini. Dimulai dari pengenalan data set data panel, pnegecekan persebaran data masing-masing daerah, penggabungan persebaran data masing-masing daerah penelitian.

Hasil yang dipaparkan oleh penulis dalam bab ini sudah mengalami perbaikan model atas adanya masalah dalam asumsi klasik dan sudah diuji normalitas datanya ( stationeritas). Serta menghilangkan masalah-masalah dalam uji BLUE (Best Linear Unbiassed Estimator), yaitu autokorelasi, multikorelasi, dan heteroskedastisitas dalam model dengan menggunakan perbaiakna data dengan menggunakan model Robust dan merubah model kedalam bentuk GLS (General Least Square) dengan menggunakan software Stata 11.

Analisis dalam model pembahasan ini sudah menghitung besaran multikolinearitas antara variabel independen maupun autokorelasi dalam model. Adapun untuk menguji stasineritas dan heteroskedastisitas juga telah dilakukan pengujian walaupun awalnya terdapat masalah tapi sudah diperbaiki agar hasil dari regresi BLUE 
Tabel 1. Chow-test Model Panel

\begin{tabular}{l}
\hline Chow test \\
\hline Nilai Probabilita F \\
Keputusan \\
$\begin{array}{l}\text { Sumber: Data sekunder diolah, } 2017 \\
\text { Fixed Effect }\end{array}$ \\
Pada tabel hasil uji chow diatas dapat disimpulkan \\
bahwa penggunaan fixed effect lebih tepat digunakan \\
pada model ini jika dibandingkan dengan menggunakan \\
metode PLS. Nilai F lebih kecil daripada critical value \\
yang memberikan kesimpulan bahwa $\mathrm{H}_{0}$ ditolak dan \\
menunjukkan model secara statistik lebih baik \\
menggunakan metode Fixed effect.
\end{tabular}

Kemudian untuk melihat pemilihan model antara Pooled Least Square (PLS) dengan Random Effect maka dilakukan uji Breusch Pagan Lagrange Multiplier (LM) dengan hasil seperti tabel dibawah.

Tabel 2. Lagrangian Multiplier (LM) Test Model Panel

\begin{tabular}{ll}
\hline Hausman & Hasil \\
\hline Nilai Probabilita $\mathrm{chi}^{2}$ & Prob $>\mathrm{chi}^{2}=0,9279$ \\
Keputusan & Pooled least square \\
\hline
\end{tabular}

Sumber: Data sekunder diolah, 2017

Pengujian menggunakan LM test dengan melihat pada hasil tabel diatas menunjukan kesimpulan bahwa penggunaan PLS lebih cocok dengan model ini daripada menggunakan model Random Effect. Dengan adanya dua hasil berbeda dari uji berbeda maka dilakukan pengujian yang ketiga yaitu hausman test.

Tabel 3. Uji Hausman Model Panel

\begin{tabular}{ll}
\hline Hausman & Hasil \\
\hline Nilai Probabilita chi $^{2}$ & Prob $>\mathrm{chi}^{2}=0.0001$ \\
Keputusan & Fixed Effect \\
\hline Sumber: Data sekunder diolah, 2017
\end{tabular}

Sumber: Data sekunder diolah, 2017

Dari hasil uji Hausman, dapat dilihat pada tabel di atas dimana nilai $c h i^{2}$ adalah sebesar 0,0001 dengan nilai $\alpha$ yaitu 5\%. Hipotesis nol untuk uji Hausman adalah perbedaan dalam hasil koefisien estimasi tidak sistematis (random effect) dan hipotesis alternatifnya adalah hasil koefisien estimasi sistematis (fixed effect). Dari hasil probabilita chi yang di bawah tingkat kepercayaan 95\% maka model yang digunakan adalah fixed effect dengan menerima hasil hipotesis nol dari uji Hausman.

Gujarati (2004) menjelaskan bahwa adanya multikolinearitas terjadi apabila korelasi parsial antara variabel lebih dari 0.8 atau sebesar 80 persen atau lebih. Tabel 4 berikut menunjukan bahwa dalam model ini tidak ditemukan multikolinearitas. Hal ini dapat dilihat dari tabel diatas bahwa hubungan antara variabel tidak ada yang mencapai 0.8 atau lebih.dimana hubungan paling tinggi pada tabel 4 berikut adalah rasio antara DAU dengan Rasio DBH sebesar 76,96 \%

Tabel 4. Uji Multikolinearitas dalam Model Panel

\begin{tabular}{llllll}
\hline & $\begin{array}{l}\text { PDRB } \\
\text { Deflator }\end{array}$ & DBH & DAU & DAK & Retribusi \\
\hline PDRB Deflator & 1,0000 & & & & \\
Rasio DBH & 0.5885 & 1,0000 & & & \\
Rasio DAU & -0.360 & -0.769 & 1,0000 & & \\
Rasio DAK & 0.0258 & -0.276 & 0.371 & 1,0000 & \\
Retribusi & -0.4997 & -0.357 & 0.2078 & -0.174 & 1,0000 \\
\hline
\end{tabular}

Sumber: data sekunder diolah, 2017

Tabel 5. Uji Multikolinearitas Model Panel dengan metode VIF

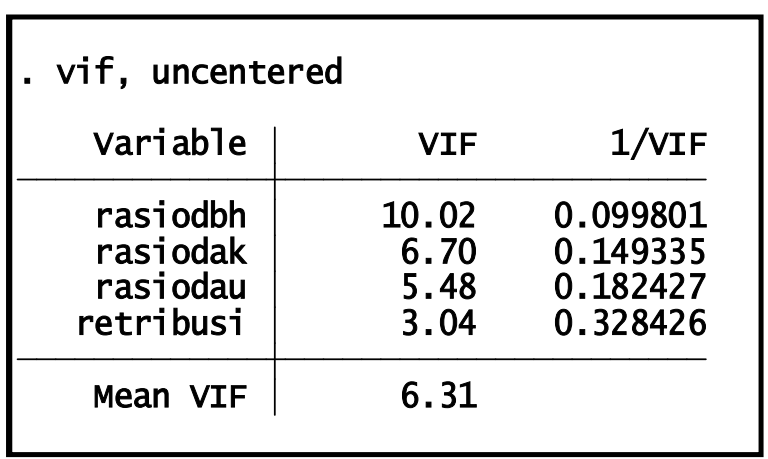

Sumber: Data sekunder diolah, 2017

Dari tabel 4.10 diatas dapat dilihat nilai mean VIF yaitu 6.31, adanya multikolinearitas dalam model jika nilai mean VIF lebih besar dari 10 atau tolerance (1/VIF) adalah 0.01. jadi dapat disimpulkan bahwa model diatas tidak terdapat multikolinearitas karena nilai men VIF berada dibawah 10 .

Tabel 6. Hasil Pengujian autokorelasi sebelum perbaikan model

xtserial pdrbdeflator rasiodbh rasiodau rasiodak retribusi
Wooldridge test for autocorrelation in panel data
HO: no first-order autocorrelation
$\mathrm{F}(1, \quad 9)=\quad 8.510$
Prob $>\mathrm{F}=\quad 0.0171$

Sumber: Data sekunder diolah, 2017

Pada tabel diatas diketahui bahwa nilai Prob $>\mathrm{F}=$ 0.0171 , dengan hipotesis $\mathrm{H} 0=$ tidak ada autokorelasi dan $\mathrm{Ha}=$ Autorelasi, dengan kriteria tolak $\mathrm{H0}$ jika nilai Prob $>$ F lebih kecil daripada alfa. Nilai alfa adalah 0.05 sedangkan nilai Prob $>\mathrm{F}=0.0171$ maka H0 ditolak, berarti dalam persamaan ini terdapat autokorelasi. Untuk menghilangkan penyakit autokorelasi maka model harus dirubah kedalam persamaan yang BLUE dengan menggunakan model General Least Square (GLS) 
Tabel 7. Pengujian heteroskedastisitas dan autokorelasi setelah perbaikan model

\begin{tabular}{|c|c|c|c|c|c|c|}
\hline \multicolumn{7}{|c|}{$\begin{array}{l}\text { xtgls pdrbdeflator rasiodbh rasiodau ra } \\
\text { Cross-sectional time-series FGLS regressi } \\
\text { Coefficients: generalized least squares } \\
\text { Panels: } \\
\text { Correlation: nomoskedastic } \\
\text { no autocorrelation }\end{array}$} \\
\hline \multicolumn{2}{|c|}{$\begin{array}{l}\text { Estimated covariances } \\
\text { Estimated autocorrelations } \\
\text { Estimated coefficients } \\
\text { Log 1ikelihood }\end{array}$} & \multicolumn{2}{|c|}{$\begin{array}{r}1 \\
0 \\
14 \\
6854\end{array}$} & \multicolumn{2}{|c|}{$\begin{array}{l}\text { Number of obs } \\
\text { Number of groups } \\
\text { Time periods } \\
\text { Wald chi2(13) } \\
\text { Prob > chi2 }\end{array}$} & $\begin{array}{r}50 \\
10 \\
5 \\
157.30 \\
0.0000\end{array}$ \\
\hline pdrbdeflator & coef. & Std. Err. & z & $P>|z|$ & [95\% Conf. & Interva1] \\
\hline $\begin{array}{l}\text { rasiodbh } \\
\text { rasiodau } \\
\text { rasiodak } \\
\text { retribusi }\end{array}$ & $\begin{array}{r}.1290144 \\
.5825024 \\
-.4592334 \\
-.0003764\end{array}$ & $\begin{array}{l}.2722842 \\
.1320809 \\
.4834038 \\
.0000792\end{array}$ & $\begin{array}{r}0.47 \\
4.41 \\
-0.95 \\
-4.75\end{array}$ & $\begin{array}{l}0.636 \\
0.000 \\
0.342 \\
0.000\end{array}$ & $\begin{array}{r}-.4046528 \\
-1.3236286 \\
-.0005315\end{array}$ & $\begin{array}{r}.6626817 \\
.8413761 \\
.4882205 \\
-.0002212\end{array}$ \\
\hline $\begin{array}{r}\text { daerah } \\
2 \\
3 \\
4 \\
5 \\
6 \\
7 \\
8 \\
9 \\
10\end{array}$ & $\begin{array}{r}-6.756475 \\
2.575241 \\
3.081437 \\
5.4668 \\
-.0692136 \\
-2.721427 \\
-7.284841 \\
19.94395 \\
-4.94681\end{array}$ & $\begin{array}{l}2.312629 \\
2.230927 \\
2.369223 \\
2.714365 \\
2.188611 \\
2.533739 \\
2.404506 \\
4.887272 \\
2.787739\end{array}$ & $\begin{array}{r}-2.92 \\
1.15 \\
1.30 \\
2.01 \\
-0.03 \\
-1.07 \\
-3.03 \\
4.08 \\
-1.77\end{array}$ & $\begin{array}{l}0.003 \\
0.248 \\
0.193 \\
0.044 \\
0.975 \\
0.283 \\
0.002 \\
0.000 \\
0.076\end{array}$ & $\begin{array}{r}-11.28914 \\
-1.797296 \\
-1.562156 \\
-1467419 \\
-4.358812 \\
-7.687464 \\
-11.99759 \\
10.36507 \\
-10.41068\end{array}$ & $\begin{array}{r}-2.223805 \\
6.947778 \\
7.725029 \\
10.78686 \\
4.220385 \\
2.24461 \\
-2.572096 \\
29.52283 \\
.5170581\end{array}$ \\
\hline _cons & 65.15515 & 10.206 & 6.38 & 0.000 & 45.15175 & 85.15855 \\
\hline
\end{tabular}

Sumber: Data sekunder diolah, 2017

Dalam permasalahan uji asumsi klasik yang lain seperti heteroskedastisitas dan autokorelasi dalam penelitian ini, penulis mengatasi permasalan tidak BLUE di model panel dengan melakukan perubahan ke dalam model robust dan model Genaral Least Square (GLS) dengan menggunakan regresi fixxed effect. Dari hasil pengolahan stata diatas diatas sudah jelas bahwa coefisient sudah dalam bentuk geneeralized least square. Model panelnya homoskedastic, artinya dalam model sudah tidak terdapat heteroskedastisitas. Dan dari hasil diatas secara jelas bahwa tidak terdapat autokorelasi.

Hasil estimasi yang ditemukan menunjukkan bahwa ketiga metode menghasilkan estimasi yang serupa khususnya untuk variabel utama yaitu komponen dana perimbangan. Dapat dilihat bahwa rasio $\mathrm{DBH}$, dan rasio DAU, dan Rasio DAK memiliki hubungan yang cukup signifikan dan positif terhadap inflasi daerah sedangkan Retribusi memiliki hubungan yang negatif dengan inflasi di Kabupaten / Kota di Nusa Tenggara Barat dengan tingkat kepercayaan sebesar 46,14 persen baik dengan menggunakan metode efek acak maupun metode efek tetap serta metode pooled least square. Untuk semua variabel independen dapat dilihat bahwa dengan menggunakan ketiga metode tersebut tetap menunjukkan hasil yang sama yaitu memiliki pengaruh yang kecil terhadap Inflasi yang diproksi dari PDRB Deflator daerah Nuasa Tenggara Barat. Hal ini ditunjukkan ketika menggunakan metode efek acak, efek tetap maupun pooled least square hasilnya tidak ada perbedaan, ini menunjukan bahwa jumlah data yang digunakan dalam penelitian ini masih kurang dan belum bisa mewakili hasil estimasi yang dimaksudkan. 
Tabel 8. Hasil Regresi Fixed effect Dengan Metode Robust

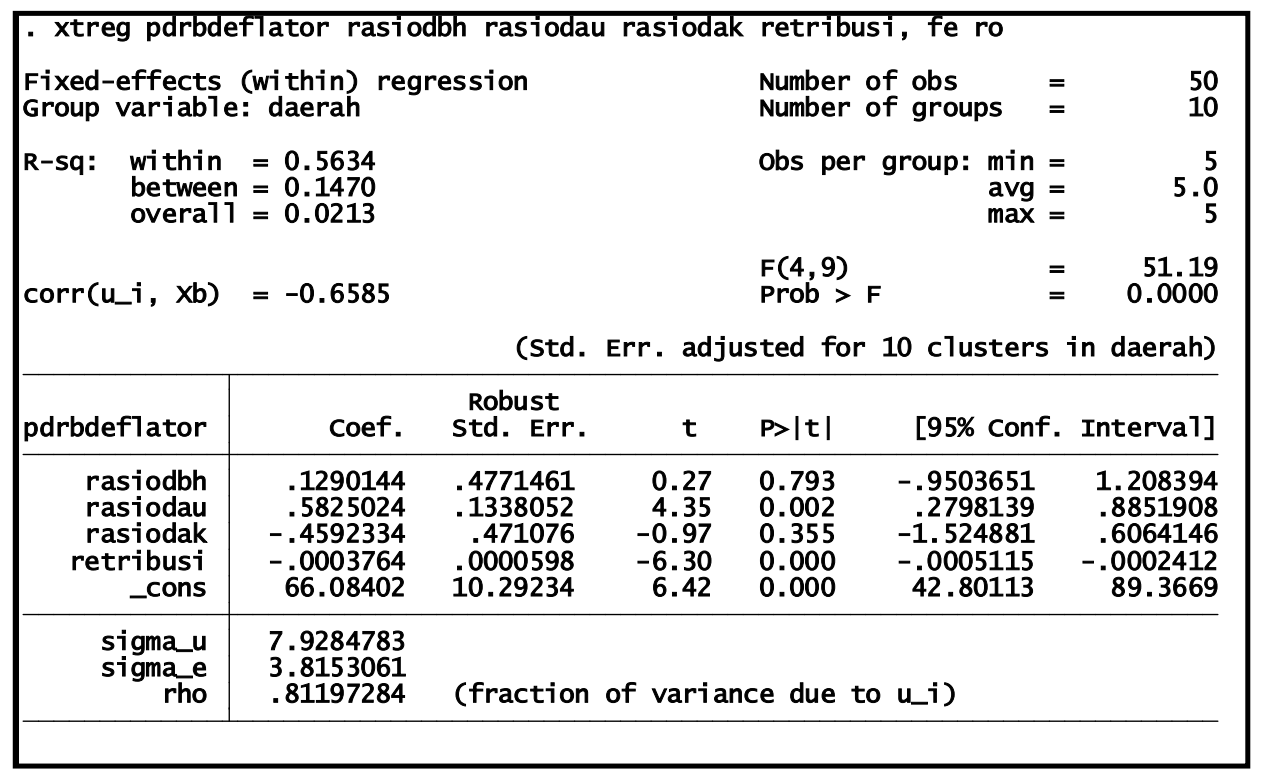

Sumber: Data sekunder diolah, 2017

Tabel diatas menunjukan hasil estimasi pada model panel menggunakan regresi fixed effect yang sudah diperbaiki. Secara statistik, sebagaimana yang sudah dipaparkan pada tabel uji sebelumnya model panel ini disarankan menggunakan fixed effect. Dengan menggunakan efek tetap menandakan bahwa pengambilan eror dilakukan secara tetap dalam mengestimasi model tersebut. Namun pada pembahasan sebelumnya penulis telah melakukan pembangdingan antara metode fixed effect dan metode random eefect yang menggunakan eror secara sistematis pada setiap data observasi yang dilakukan.

Pada tabel diatas kita dapat melihat bahwa terdapat tiga jenis nilai R-squared yaitu R-square within, Rsqured between dan $\mathrm{R}$ squared overal. Dalam kaitan model yang digunakan penulis yatu fixeed effect adalah $\mathrm{R}$ squared within dengan angka sebesar 0.5634 yang artinya adalah variabel independen bersama-sama dapat menjelaskan model secara keseluruhan sebesar 56.34 persen. Yang artinya nilai R-squared ini tidak terlalu rendah dan tidak terlalu tinggi.

Uji signifikansi serentak (F-Test), Diamana Uji ini digunkan untuk melihat secara global, apakah semua variabel independen secara bersama-sama mempengaruhi variabel dependennya. Hipotesanya sebagai berikut:

$$
\begin{aligned}
& \mathrm{H} 0: \beta 1=\beta 2=\beta 3=\beta 4=0 \\
& \mathrm{H} 1: \beta 1 \neq \beta 2 \neq \beta 3 \neq \beta 4 \neq 0
\end{aligned}
$$

Hipotesa nol akan ditolak bila $($ Prob $>\mathrm{F})<\alpha$ atau nilai $\mathrm{t}$-stat $>$ nilai kritis t-tabel. Dari tabel diatas uji global $\mathrm{F}$ dapat membuktikan apakah benar variabel DBH, DAU, DAK, dan Rtribusi secara bersama-sama mempengaruhi variabel Inflasi. Pada tabel diatas nilai dari $($ Prob $>$ F $)=$ 0.0001 . ini berarti (Prob $>$ F) lebih kecil $\alpha$ dengan nila 0.05, maka kita tidak cukup bukti untuk menerima H0, yang berarti semua variabel independent tersebut mampu menjelaskan atau mempengaruhi variabel dependent dan modelnya signifikan

Uji signifikansi parsial (t-test). Uji ini untuk melihat secara individual, apakah masing-masing variabel independen secara signifikan berpengaruh terhadap variabel dependen. Hipotesanya sebagai berikut:

$$
\begin{aligned}
& \mathrm{HO}: \beta \mathrm{k}=0 \\
& \mathrm{H} 1: \beta \mathrm{k} \neq 0
\end{aligned}
$$

Hipotesa nol akan ditolak bila $(\mathrm{P}>|\mathrm{t}|)<\alpha$ atau nilai t-stat $>$ nilai kritis ttabel. Dari tabel diatas, uji global t dapat membuktikan apakah benar variabel DBH, DAU, DAK, Retibusi secara terpisah mempengaruhi variabel Inflasi.

Tabel 9. Nilai $(\mathrm{P}>|\mathrm{t}|)$ dan $\alpha$ untuk masing-masing variabel

\begin{tabular}{lll}
\hline Variabel Independen & $(\mathrm{P}>|\mathrm{t}|)$ & $\mathrm{A}$ \\
\hline Rasio Dana bagi hasil & 0.793 & 0.05 \\
Rasio Dana alokasi umum & 0.002 & 0.05 \\
Rasio Dana alokasi khusus & 0.355 & 0.05 \\
Retribusi & 0.000 & 0.05 \\
\hline Susi
\end{tabular}

Sumber: Data sekunder diolah, 2017

Dari tabel diatas kita dapat melihat secara jelas nilai dari masing-masing variabel independen dimana ada dua variabel yang nilai $(\mathrm{P}>|\mathrm{t}|)$ dibawah nilai alfa yaitu dana alokasi umum dan retribusi, ini menunjukan bahwa tidak cukup bukti untuk menerima H0 sehingga dapat diambil kesimpulan bahwa dana alokasi umum dan retribusi dapat menjelaskan model regresi terhadap variabel dependen. Sementara untuk variabel dana bagi 
hasil dana alokasi khusus, dengan nilai $(\mathrm{P}>|\mathrm{t}|)$ diatas alfa maka kita punya cukup bukti untuk menerima $\mathrm{H} 0$ yang berarti variabel independen tersebut belum bisa menjelaskan variabel dependen secara

Dari hasil statistik pengelolaan stata bahwa dana bagi hasil berepengaruh poitif terhadap inflasi dengan nilai koefisien 0.01531. artinya hasil dari pengujian statistik ini sesuai dengan studi yang dilakukan Roosen bahwa DBH berpengaruh positif terhadap inflasi. Ada dua faktor yang menyebabkan DBH berpengaruh positif terhadap inflasi yaitu jumlah sumber daya alam kabupaten kota di NTB yang banyak yang sebagian besar dikelola oleh pemerintah pusat sehingga kabupaten kota tersebut memperoleh dana yang cukup besar dari pemerintah pusat. Penggunaan dana bagi hasil kabupaten kota di NTB lebih difokuskan ke sektor infratruktur yang mendorong permintaan agregat sehingga menimbulkan efek pengganda dari belanja pemerintah.

Dari hasil pengujian statistik dengan stata bahwa DAU berpengaruh positif terhadap inflasi dengan nilai koefisien sebesar 0.5825024. ada beberapa faktor yang menyebabkan DAU berpengaruh positif terhadap inflasi di kabupaten kota di NTB. Yang yaitu dari kategori celah fiskal yang mana pengalokasian DAU berdasarkan jumlah gaji pegawai di daerah tersebut, dimana penggunaan DAU untuk pembayaran gaji pegawai lebih dari $50 \%$. Sebagai contoh kabupaten sumbawa tahun 2014 membayar gaji pegawai sebesar Rp 647,1 milyar.

Tabel 10. Hasil, Hipotesis, dan Interpretasi Model

\begin{tabular}{|c|c|c|c|}
\hline Variabel & Hipotesis & Hasil & Interpretasi \\
\hline Rasio DBH & $\begin{array}{l}\text { Pengaruh } \\
\text { positif }\end{array}$ & $\begin{array}{l}\text { Berpengaruh positif } \\
\text { dengan } \quad \text { koefisien } \\
\text { sebesar } 0.1290144\end{array}$ & $\begin{array}{l}\text { Pertambahan } 1 \text { satuan rasio dana bagi hasil pajak dan } \\
\text { SDA terhadap APBD masing-masing Kabupaten di } \\
\text { NTB menyebabkan inflasi naik sebesar } 0.1290114 \\
\text { satuan }\end{array}$ \\
\hline Rasio DAU & $\begin{array}{l}\text { Pengaruh } \\
\text { Positif }\end{array}$ & $\begin{array}{l}\text { Berpengaruh positif } \\
\text { dengan koefisien } \\
\text { sebesar } 0.5825024\end{array}$ & $\begin{array}{l}\text { Pertambahan } 1 \text { satuan rasio dana alokasi umum } \\
\text { terhadap APBD masing-masing Kabupaten di NTB } \\
\text { menyebabkan inflasi naik sebesar } 0.5825024 \text { satuan }\end{array}$ \\
\hline Rasio DAK & $\begin{array}{l}\text { Pengaruh } \\
\text { Positif }\end{array}$ & $\begin{array}{l}\text { Berpengaruh negatif } \\
\text { dengan } \quad \text { koefisien } \\
\text { sebesar }\end{array}$ & $\begin{array}{l}\text { Pertambahan } 1 \text { satuan rasio dana aloasi khusus } \\
\text { terhadap APBD masing-masing Kabupaten di NTB } \\
\text { menyebabkan inflasi berkurang sebesar } 0.4592334 \\
\text { satuan }\end{array}$ \\
\hline Retribusi & $\begin{array}{l}\text { Pengaruh } \\
\text { Positif }\end{array}$ & $\begin{array}{l}\text { Berpengaruh negatif } \\
\text { dengan koefisien } \\
\text { sebesar } 0.0003764 \\
\end{array}$ & $\begin{array}{l}\text { Pertambahan } 1 \text { satuan retribusi yang diterima masing- } \\
\text { masing Kabupaten di NTB menyebabkan inflasi } \\
\text { berkurang sebesar } 0.0003764 \text { satuan }\end{array}$ \\
\hline
\end{tabular}

\section{Kesimpulan}

1. Secara statistik Rasio DAK terhadap APBD berpengaruh negatif terhadap inflasi di NTB yaitu ketika DAK naik satu satuan maka inflasi di NTB akan berkurang sebesar 0,1290144 satuan. Berdasarkan data dari DJPK kementrian keuangan DAK secara spesifik diprioritaskan untuk tiga
Sementara jumlah DAU kabupaten sumbawa tahun 2014 adalah Rp 724,9 milyar. Yang kedua dari kategori selisih fiskal, kabupaten kota di NTB rata rata kebutuhan daerahnya lebih besar daripada potensi daerahnya sehingga menyebabkan inflasi.

Dana Alokasi Khusus berdampak negatif terhadap inflasi dengan koefisien sebesar 0.4592334. hal ini sejalan dengan penelitian Bird dan Smart bahwa Dak berpegaruh negatif terhadap inflasi. Ada beberapa faktor yang menyebabkan DAK berpengaruh negatif terhadap inflasi yaitu Penggunaan DAK di kabupaten kota di NTB lebih difokuskan pada bidang kesehatan dan pariwisata dan pendidikan yang sejalan dengan penelitian Bird dan Smirt bahwa DAK bidang pendidikan dan kesehatan pada akhirnya dapat meningkatkan produktivitas daerah tertinggal, dan dengan produktifitas yang handal tersebut sehingga harga-harga kan stabil karena tidak adanya kelangkaan di pasar sehingga inflasi dapat ditekan. Sebagai contoh kabupaten sumbawa tahun 2014 dengan jumlah DAK sebesar Rp 81,24 milyar dimana belanja pendidikan melebihi $50 \%$ dari jumlah DAK sehingga berpengaruh negatif terhadap inflasi. Retribusi berpengaruh negatif terhadaf inflasi Nusa Tenggara Barat dengan koefisien sebesar 0.0003764 yang artinya semakin besar retribusinya maka inflasi semakin kecil, ini menyiratkan semakin besar pendapatan retribusi pemerintah menyebabkan jumlah uang yang beredar di masyarakat berkurang. 
2. Rasio DAU Terhadap APBD berpengaruh positif terhdap inflas di NTB berdasarkan hasil pengujian secara statistik dengan koefisien sebesar 0.5825204. Dari kategori celah fiskal dimana dimana penggunaan DAU di kabupaten kota di NTB digunakan untuk pembayaran gaji pegawai lebih dari 50\%. Sebagai contoh kabupaten sumbawa tahun 2014 membayar gaji pegawai sebesar Rp 647,1 milyar. Sementara jumlah DAU kabupaten sumbawa tahun 2014 adalah Rp 724,9 milyar. Yang kedua dari kategori selisih fiskal, kabupaten kota di NTB rata rata kebutuhan daerahnya lebih besar daripada potensi daerahnya sehingga menyebabkan inflasi dan hal ini sejalan dengan penelitian Ranouli tahun 2006

3. Secara statistik berdasarkan hasil pengujian software stata rasio DBH terhadap APBD berpengaruh positif terhadap inflsi di provinsi Nusa Tenggara Barat sebesar 0,4592334. hasil dari pengujian statistik ini sesuai dengan studi yang dilakukan Roosen bahwa DBH berpengaruh positif terhadap inflasi. Ada dua faktor yang menyebabkan DBH berpengaruh positif terhadap inflasi yaitu jumlah sumber daya alam kabupaten kota di NTB yang banyak yang sebagian besar dikelola oleh pemerintah pusat sehingga kabupaten kota tersebut memperoleh dana yang cukup besar dari pemerintah pusat. Penggunaan dana bagi hasil kabupaten kota di NTB lebih difokuskan ke sektor infratruktur yang mendorong permintaan agregat sehingga menimbulkan efek pengganda dari belanja pemerintah.

4. Secara statistik retribusi berpengaruh negatif dan signifikan terhadap inflasi di NTB dengan koefisien 0,0003764 ini menunjukan semakin besar retribusinya maka inflasi semakin kecil, ini menyiratkan semakin besar pendapatan retribusi pemerintah menyebabkan jumlah uang yang beredar di masyarakat berkurang.

5. Secara statistik didapatkan bukti bahwa Rasio DAK, DAU, DBH, dan retribusi secara bersamasama berpangaruh terhadap inflasi berdasarkan hasil uji $\mathrm{F}$ dengan nilai dari $($ Prob $>\mathrm{F})=0.0001$. ini berarti (Prob $>$ F) lebih kecil $\alpha$ dengan nila 0.05 , yang berarti semua variabel independent tersebut mampu menjelaskan atau memengaruhi variabel dependen secara signifikan

\section{Saran}

Agar kebijakan desentralsaisi fiskal dapat sejalan dengan tujuan awalnya yaitu pemerataan pembangunan ekonomi maka diharapkan agar pemerintah dapat memperhatikan aspek ketergantungan pemerintah daerah. Hal ini melihat bahwa kondisi daerah yang relatif terlalu mengandalkan dana perimbangan seperti DAK, DBH, dan DAU sebagai sumber penerimaan utama sehingga meningkatkan rasio perbandingan dana perimbangan terhadap PAD dan melupakan kekuatan dari PAD Seperti Retribusi.

Selain itu melihat bahwa hanya rasio DBH, Rasio DAU yang berpengaruh terhadap inflasi di NTB ini menunjukan bahwa desentarlisasi fiskal di NTB memiliki pengaruh yang baik terhadap perekonomian daerah walaupun salah indikator yang menyebablkan inflasi, sehingga inflasi dibutuhkan untuk mendorong pertumbuahan ekonomi di NTB terutama di sektor pariwisata.

\section{Daftar Pustaka}

Restiatun (2005), Pengaruh Desentralisasi Fiskal Terhadap inflasi, Universitas Gadjah mada

Tirtosuharto Darius dan Handri Adiwilaga (2013), Decentralization and Regional Inflation in Indonesa, Buletin Ekonomi Moneter dan Perbankan, Oktober 2013

Katalog Badan pusat Statistik (2015), Produk Domestik Regional Bruto Kbupaten/Kota di Indonesia 2010-2014

Katalog Badan Pusat Statistik (November 2015), Tinjuan Regional berdsarkan PDRB Kabupaten/Kota 2010-2014 Pulau Nusa Tenggara, maluku, dan Papua.

N.Dachlan Akbar (Januari 2012), Pengaruh Dana Perimbangan Terhadap Pertumbuhan Ekonomi Regional Pada Era Desentralisasi Fiskal, Universitas Indonesia

Akai Nabuo dan Masayo Sakata (2002), Fiscal desentralization Contributes to economic growth, Academic Press

Brojonegoro Bambang (2001), Indonesia Intergovermental Transfer In Decentralization Era: The case Of General Allocation Fund, (LPEM-FEUI)

Mulyana Budi, Subkhan dan Kuwat Slamet (2006), Keungan Daerah, Perspektif Desentralisasi Fiskal dan Pengelolaan APBD di Indonesia, Lembaga Pengkajian Keuangan Publikdan Akuntansi Pemerintah (LPKPAP) Badan Pendidikan dan Pelatihan keuangan (BPPK)

Jurnal Ekonomi Studi Pembangunan (2009), Delibrate Inflation Pada Kebijakan Desentralisasi Fiskal Jawa Timur dan Dampaknya Bagi Pertumbuhan Daerah, JSEP Vol, 1, No. 3, 2009

Suwardi Akbar (2011), Stata: Tahapan dan Perintah (Syntax) data Panel, Laboratorium 
Komputasi Departemen Ilmu Ekonomi Fakultas Ekonomi Universitas Indonesia

Arsyad Lincolin (2010), Ekonomi Pembangunan, Edisi 5, LPP STIM YKPM

Gujarati damodar (2004), Basic Econometrics, Four Edition, The McGraw Companies, 2004

Mulyawan Budi, Subkhan, Kuwat Slamet (2006), Keuangan Daerah : Perspektif Desentralisasi Fiskal dan Pengelolaan APBD di Indonesia, Badan Diklat Keuangan.

Baltagi Badi H (2005), Econometric Analysis of panel Data ( Thitd Edition ), John Wiley \& Sons Ltd, The Atrium, Sothem Gate, Chichester, West Sussex, England
StataCorp LP (2009), Stata Longitudinal-Data/PanelData Reference Manual, Release 11, Stata Press, 4905 Lakeway Drive College Station, Texas.

Siagian Altito R (2010), Pengaruh Desentralisasi Fiskal Terhadap Pertumbuhan Ekonomi Daerah dan Ketimpamgam Wilayah di Jawa Barat, Universitas Diponegoro semarang.

Damayanti Meutia irma (2014), Pengaruh pendapatan Asli Daerah, Dana Bagi Hasil, dana Alokasi Umum, dan Dana Alokasi Khusus Terhadap Indeks Pembangunan Manusia di provinsi Nusa tenggara Barat Periode Tahun 20092012, UIN Syarif Hidayatullah Jakarta 